\title{
Phylogenetic and Molecular Profile of Staphylococcus aureus Isolated from Bloodstream Infections in Northeast Brazil
}

\author{
Andrea de S. Monteiro ${ }^{1}$, Bruna L. S. Pinto ${ }^{1}$, Joveliane de M. Monteiro ${ }^{1}$, Rômulo M. Ferreira ${ }^{1}$, \\ Patrícia C. S. Ribeiro $^{2}$, Silvia Y. Bando ${ }^{3}{ }^{\mathbb{C}}$, Sirlei G. Marques ${ }^{2,4}$, Luís C. N. Silva ${ }^{1}{ }^{\mathbb{C}}$, \\ Wallace R. Nunes Neto ${ }^{1}$, Gabriella F. Ferreira ${ }^{5}$, Maria Rosa Q. Bomfim ${ }^{1}$ and \\ Afonso G. Abreu 1,6,* (iD \\ 1 Programa de Pós-Graduação, Universidade Ceuma, São Luís 65075-120, Brazil \\ 2 Laboratório Cedro, São Luís 65020-570, Brazil \\ 3 Departamento de Pediatria, Faculdade de Medicina da Universidade de São Paulo (FMUSP), \\ São Paulo 01246-903, Brazil \\ 4 Hospital Universitário da Universidade Federal do Maranhão, São Luís 65020-070, Brazil \\ 5 Departamento de Farmácia, Universidade Federal de Juiz de Fora, Governador Valadares 35010-177, Brazil \\ 6 Programa de Pós-Graduação em Ciências da Saúde, Universidade Federal do Maranhão, \\ São Luís 65080-805, Brazil \\ * Correspondence: abreu.ag@hotmail.com
}

Received: 10 May 2019; Accepted: 11 July 2019; Published: 22 July 2019

\begin{abstract}
Staphylococcus aureus is a notorious human pathogen associated with serious nosocomial and community-acquired infections, such as pneumonia, meningitis, endocarditis, toxic shock syndrome, and sepsis, among others. The objective of this study was to investigate the molecular profile, antimicrobial resistance, and clonal diversity of S. aureus isolated from the bloodstream. The determination of the minimum inhibitory concentration (MIC) of the antimicrobial was performed by an automated method. The presence of several virulence and resistance genes was evaluated by PCR. In addition, multilocus sequence typing (MLST) was used to analyze the clonal diversity of S. aureus. A high resistance to oxacillin (78\%), clindamycin (78\%), erythromycin $(70 \%)$, ciprofloxacin $(61 \%)$, and gentamicin $(52 \%)$ was observed among the isolates. In most of them, the following virulence genes were detected: hlb (83\%), ebpS (61\%), icaA (57\%), fnbpA $(17 \%)$, and clfA $(13 \%)$. Only one isolate carried the $p v l$ gene. MLST analysis identified five new sequence types (STs): 5429, 5430, 5431, 5432, and 5433, as well as another seven-ST5, ST97, ST398, ST101, ST30, ST461, and ST2779-among the remaining strains. These seven STs and the four new STs are clustered in four clonal complexes: CC1, CC2, CC7, and CC17. Phylogenetic analysis showed the genetic relationship of the five new ST strains with another 18 strains. Altogether, these analyses indicate the horizontal transfer acquisition of virulence factor genes and multidrug resistance.
\end{abstract}

Keywords: Staphylococcus aureus; bloodstream infection; multilocus sequence typing (MLST); antimicrobial resistance

\section{Introduction}

Nosocomial infections remain among the leading causes of mortality worldwide, with millions of deaths globally each year. These clinical conditions result in high economic and social costs for society. The infection severity is increased by some factors, such as the immunocompromised state of the patient and the presence of bacteria strains with a multidrug-resistance profile [1-4]. The use 
of medical devices is also considered an important risk factor for the development of bloodstream infections that are the leading cause of death for hospitalized patients [5].

Staphylococcus aureus is a frequent agent of potentially fatal bloodstream infections, especially due to its remarkable ability to colonize different superficies (including medical devices) and to spread in several environments. The estimated incidence of $S$. aureus-induced bloodstream infections is around 80 to 190 cases/100,000 inhabitants per year in developed countries [6-8]. The development of several mechanisms of virulence by $S$. aureus has ensured its success during systemic infections, which include factors involved in human immune system evasion, surface proteins, secreted enzymes, and toxins that damage the host membranes $[9,10]$.

From the repertoire of enzymes for virulence, hemolysins produced by S. aureus are an important factor, with cytotoxic action responsible for lysing erythrocytes and culminating in a worsening of clinical symptoms during bloodstream infections [11]. Other toxins like those forming pores in leukocytes, such as Panton Valentine leukocidin (PVL), may aggravate pulmonary infections in episodes of necrotizing pneumonia [12]. In addition, S. aureus also has the ability to utilize fibronectin-binding protein A (FnBPA) to adhere to and consequently be internalized into host cells. This results in longer persistence in the tissues, as well as evasion from the attack of the immune system [13]. Another important virulence factor is elastin-binding protein (EbpS), a microbial surface component recognizing the adhesive matrix molecule that mediates bacterial cell binding to soluble elastin and tropoelastin [14].

Furthermore, S. aureus has acquired great medical importance due its ability to become resistant to multiple antimicrobial drugs through different molecular pathways [15]. The classical example is the emergence of methicillin-resistant S. aureus (MRSA) strains, which raises great concerns worldwide. MRSA is estimated to cause millions of deaths per year in the US [16,17], and the prevalence of MRSA in Latin America appears to be very heterogeneous, ranging from $6 \%$ in Central America to $80 \%$ in some South American countries, including Brazil $[8,18,19]$. The $\beta$-lactam resistance in S. aureus is primarily due to expression of the mecA gene, which is present on the chromosome in a resistance cassette, called Staphylococcal Cassette Chromosome (SCC) mec, which encodes the low affinity penicillin-binding protein (PBP2a) [20]. Besides MRSA, other strains of S. aureus have been detected as multidrug-resistant $(M D R)$ and showing resistance towards last-resort drugs such as vancomycin (VRSA) and linezolid [21,22].

Therefore, the early detection of the arsenal of virulence and drug resistance genes in S. aureus is an important task in order to efficiently track the MDR and hypervirulent strains associated with high levels of morbidity/mortality. The purpose of the present study was to investigate the genetic diversity and antimicrobial susceptibility of $S$. aureus isolated from bloodstream infections in patients hospitalized in Intensive Care Units (ICUs) in different public hospitals in São Luis (Maranhão state, Northeast Brazil), as well as to compare the phylogenetic profile among the isolates.

\section{Material and Methods}

\subsection{Bacterial Strains}

S. aureus analyzed in this study were obtained from positive blood cultures after incubation in Bactec Plus Aerobic/F and Bactec Lytic/10Anaerobic/F blood culture bottles (Becton Dickinson, Sparks, MD, USA). The blood samples were collected from patients treated at different public hospitals in São Luis, Northeast Brazil, during a period of seven months. The isolation from positive blood cultures was performed using blood agar plates (BioMérieux, Marcy l'Etoile, France). Subsequently, the isolates were identified by MALDI-TOF (Matrix Assisted Laser-Desorption Ionization-Time of Flight) Mass Spectrometry (MS). The mass spectra acquired for each bacterial strain were compared to the mass spectra contained in the database using Biotyper 3.0 software (Bruker, Billerica, MA, USA). All isolates were kept in Luria-Bertani broth supplemented with $15 \%$ glycerol at $-80{ }^{\circ} \mathrm{C}$. 


\subsection{Antimicrobial Susceptibility Testing}

The antimicrobial susceptibility profile of each $S$. aureus isolate was determined using AST\#105 and GP-ID cards by the VITEK®2 Compact system (BioMérieux, Marcy l'Etoile, France), according to the Clinical Laboratory Standards Institute (CLSI, 2016). All S. aureus isolates were tested for their susceptibility to the following antibiotics: oxacillin, erythromycin, clindamycin, gentamicin, rifampicin, teicoplanin, vancomycin, trimethoprim/sulfamethoxazole, ciprofloxacin, and linezolid.

\subsection{Analysis of Virulence and Resistance Genes}

The presence of several virulence (clfA, cna, ebpS, eta, etb, fnbp A, hla, hlb, hlg, icaA, pvl, sdrE, sea, seb, sec, sed, see, seg, seh, sei, sej, sirB) and resistance genes (blaZ and mecA) was assessed by PCR. Primer sequences, sizes of amplified products, and annealing temperatures are described in Table 1. Amplification reactions were performed in a total volume of $25 \mu \mathrm{L}$ containing $1 \mathrm{U}$ reaction buffer of GoTaq Green Master Mix (Promega Corporation, Madison, USA), $0.25 \mu \mathrm{M}$ of each primer and $20 \mathrm{ng}$ of template DNA extracted.

Table 1. Primer used for PCR, size of amplified products, and annealing temperatures.

\begin{tabular}{|c|c|c|c|c|}
\hline Gene & Primer Sequence $\left(5^{\prime}-3^{\prime}\right)$ & $\begin{array}{c}\text { Annealing } \\
\text { Temperature }\left({ }^{\circ} \mathrm{C}\right)\end{array}$ & $\begin{array}{l}\text { Size of PCR } \\
\text { Product (bp) }\end{array}$ & Reference \\
\hline Beta-lactamase (blaZ) & $\begin{array}{l}\text { (F) ACTTCAACACCTGCTGCTTTC } \\
\text { (R) TGACCACTTTTATCAGCAACC }\end{array}$ & 61 & 173 & [23] \\
\hline $\begin{array}{l}\text { Clumping factor A } \\
\text { (clfA) }\end{array}$ & $\begin{array}{l}\text { (F) GTAGGTACGTTAATCGGTT } \\
\text { (R) CTCATCAGGTTGTTCAGG }\end{array}$ & 50 & 1548 & [23] \\
\hline $\begin{array}{l}\text { Collagen adhesin } \\
\qquad(\text { can })\end{array}$ & $\begin{array}{l}\text { (F) AGTGGTTACTAATCATG } \\
\text { (R) CAGGATAGATTGGTTTA }\end{array}$ & 45 & 1722 & [23] \\
\hline $\begin{array}{l}\text { Elastin-binding } \\
\text { Protein }(e b p S)\end{array}$ & $\begin{array}{l}\text { (F) CAATCGATAGACACAAATTC } \\
\text { (R) CAGTTACATCATCATGTTTA }\end{array}$ & 50 & 506 & [23] \\
\hline $\begin{array}{l}\text { Exfoliative toxin A } \\
\qquad(\text { eta })\end{array}$ & $\begin{array}{l}\text { (F) ACTGTAGGAGCTAGTGCATTTGT } \\
\text { (R) TGGATACTTTTGTCTATCTTTTTCATCAAC }\end{array}$ & 55 & 190 & [24] \\
\hline $\begin{array}{l}\text { Exfoliative toxin B } \\
\qquad(e t b)\end{array}$ & $\begin{array}{l}\text { (F) CAGATAAAGAGCTTTATACACACATTAC } \\
\text { (R) AGTGAACTTATCTTTCTATTGAAAAACACTC }\end{array}$ & 55 & 612 & [24] \\
\hline $\begin{array}{l}\text { Fibronectin-binding } \\
\text { protein } \mathrm{A}(f n b p A)\end{array}$ & $\begin{array}{l}\text { (F) CACAACCAGCAAATATAG } \\
\text { (R) CTGTGTGGTAATCAATGTC }\end{array}$ & 50 & 1226 & [24] \\
\hline $\begin{array}{l}\text { Alpha-hemolysin } \\
\qquad(h l a)\end{array}$ & $\begin{array}{l}\text { (F) CTGATTACTATCCAAGAAATTCGATTG } \\
\text { (R) CTTTCCAGCCTACTTTTTTATCAGT }\end{array}$ & 55 & 209 & [24] \\
\hline Beta-hemolysin $(h l b)$ & $\begin{array}{l}\text { (F) GTGCACTTACTGACAATAGTGC } \\
\text { (R) GTTGATGAGTAGCTACCTTCAGT }\end{array}$ & 55 & 309 & [24] \\
\hline $\begin{array}{l}\text { Gama-hemolysin } \\
(h l g)\end{array}$ & $\begin{array}{l}\text { (F) GTCAAAGAGTCCATAATGCATTTAA } \\
\text { (R) CACCAAATGTATAGCCTAAAGTG }\end{array}$ & 55 & 535 & [24] \\
\hline $\begin{array}{l}\text { Intracellular } \\
\text { adhesion }(i c a A)\end{array}$ & $\begin{array}{l}\text { (F) GATTATGTAATGTGCTTGGA } \\
\text { (R) ACTACTGCTGCGTTAATAAT }\end{array}$ & 50 & 770 & [23] \\
\hline $\begin{array}{l}\text { Methicillin resistance } \\
\qquad(m e c A)\end{array}$ & $\begin{array}{l}\text { (F) GGTCCCATTAACTCTGAAG } \\
\text { (R) AGTTCTGCAGTACCGGATTTTGC }\end{array}$ & 57 & 163 & [23] \\
\hline $\begin{array}{l}\text { Panton-valentine } \\
\text { leucocidin }(p v l)\end{array}$ & $\begin{array}{l}\text { (F) ATCAATAGGTAAAATGTCTGGACATGATCCA } \\
\text { (R) GCATCAAATGTATTGGATAG AAAAGC }\end{array}$ & 55 & 433 & [25] \\
\hline $\begin{array}{l}\text { Serine-aspartate } \\
\text { repeat-containing } \\
\text { protein } \mathrm{E}(s d r E)\end{array}$ & $\begin{array}{l}\text { (F) CAGTAAATGTGTCAAAAGA } \\
\text { (R) TTGACTACCAGCTATATC }\end{array}$ & 50 & 749 & [23] \\
\hline Enterotoxin A (sea) & $\begin{array}{l}\text { (F) GAAAAAAGTCTGAATTGCAGGGAACA } \\
\text { (R) CAAATAAATCGTAATTAACCGAAGGTTC }\end{array}$ & 55 & 560 & [24] \\
\hline Enterotoxin B (seb) & $\begin{array}{l}\text { (F) ATTCTATTAAGGACACTAAGTTAGGGA } \\
\text { (R) ATCCCGTTTCATAAGGCGAGT }\end{array}$ & 55 & 404 & [24] \\
\hline Enterotoxin C ( $\mathrm{sec})$ & $\begin{array}{l}\text { (F) GTAAAGTTACAGGTGGCAAAACTTG } \\
\text { (R) CATATCATACCAAAAAGTATTGCCGT }\end{array}$ & 55 & 297 & [24] \\
\hline Enterotoxin D (sed) & $\begin{array}{l}\text { (F) GAATTAAGTAGTACCGCCCTAAATAATATG } \\
\text { (R) GCTGTATTTTTCCTCCGAGAGT }\end{array}$ & 55 & 492 & [24] \\
\hline Enterotoxin E (see) & $\begin{array}{l}\text { (F) CAAAGAAATGCTTTAAGCAATCTTAGGC } \\
\text { (R) CACCTTACCGCCAAAGCTC }\end{array}$ & 55 & 482 & [24] \\
\hline Enterotoxin G (seg) & $\begin{array}{l}\text { (F) AATTATGTGAATGCTCAACCCGATC } \\
\text { (R) AAACTTATATGGAACAAAAGGTACTAGTTC }\end{array}$ & 55 & 642 & [24] \\
\hline
\end{tabular}


Table 1. Cont.

\begin{tabular}{|c|c|c|c|c|}
\hline Gene & Primer Sequence $\left(5^{\prime}-3^{\prime}\right)$ & $\begin{array}{c}\text { Annealing } \\
\text { Temperature }\left({ }^{\circ} \mathrm{C}\right)\end{array}$ & $\begin{array}{l}\text { Size of PCR } \\
\text { Product (bp) }\end{array}$ & Reference \\
\hline Enterotoxin H (she) & $\begin{array}{l}\text { (F) CAATCACATCATATGCGAAAGCAG } \\
\text { (R) CATCTACCCAAACATTAGCACC }\end{array}$ & 55 & 376 & [24] \\
\hline Enterotoxin I (sei) & $\begin{array}{l}\text { (F) CTCAAGGTGATATTGGTGTAGG } \\
\text { (R) AAAAAACTTACAGGCAGTCCATCTC }\end{array}$ & 55 & 576 & [24] \\
\hline Enterotoxin J (sej) & $\begin{array}{l}\text { (F) TCAGAACTGTTGTTCCGCTAG } \\
\text { (R) GAATTTTACCAYCAAAGGTAC }\end{array}$ & 55 & 138 & [24] \\
\hline $\begin{array}{c}\text { Siderophore } \\
\text { compound } \\
\text { transporter permease } \\
\text { protein }(\operatorname{sir} B)\end{array}$ & $\begin{array}{l}\text { (F) CAGCTACGGCTACCGAAATA } \\
\text { (R) CATTTTTGGGGGCTATTGTTGT }\end{array}$ & 61 & 399 & [23] \\
\hline
\end{tabular}

\subsection{DNA Sequencing and Multilocus Sequence Typing (MLST)}

Double-stranded DNA was obtained using the Gentra Puregene kit (Qiagen, Hilden, Germany). The sequencing of the 16S rRNA nucleotide sequence and the fragments of seven housekeeping gene amplicons was performed in the Illumina platform (Ilumina Inc., San Diego, CA, USA). Reactions were performed according to the manufacturer's instructions, using the MiSeq V250 kit (Illumina Inc., San Diego, CA, USA). The primers used for the PCR amplifications were previously described [26,27]. The $16 \mathrm{~S}$ rRNA nucleotide sequence was compared with sequences in the GeneBank database, using BLASTn software to confirm the identification of the species.

Multilocus sequence typing (MLST) analysis (based on seven housekeeping genes: $\operatorname{arcC}, \operatorname{aroE}, g l p F$, $g m k, p t a, t p i$, and yqiL) was used for the identification of sequence type (ST) and clonal complex (CC). The STs were obtained through an online webtool (http://saureus.mlst.net), and the CCs were identified by eBURSTv3 software (http://eburst.mlst.net/). Moreover, the eBURST groupings were obtained using the most conservative group identification of related STs, i.e., all members in the same group share identical alleles-at least six out of seven loci-with at least one other member of the group. Additionally, we conducted a phylogenetic analysis using all seven housekeeping gene fragments and the 16S rRNA nucleotide sequence. Phylogeny was inferred using the Neighbor-Joining method [28], and genetic distances were obtained by the Kimura 2-parameter method [29]. The phylogeny construction was conducted in MEGA6 software [30].

Nucleotide sequence alignment analysis was accomplished in BioEdit Sequence Alignment Editor software (version 7.0.5), using ClustalW (University College Dublin, Dublin, Ireland). The comparative analysis was performed using a consensus sequence constructed with all 675 sequences deposited in the MLST database.

\subsection{Ethical Aspects}

This research was approved by the Research Ethics Committee of CEUMA University (protocol $\left.n^{\circ} 813.293 / 2014\right)$.

\section{Results}

\subsection{Staphyloccocus spp. Strains Presented a High Resistance Profile Towards the Tested Antimicrobials}

In this study, a total of 23,718 aerobic blood cultures from patients at different public hospitals were analyzed. Among them, 91 Staphylococcus spp. were identified: S. aureus (35 isolates), S. epidermidis (22), S. haemolyticus (21), S. hominis (6), S. capitis (2), S. warneri (2), S. caprae (1), S. saprophyticus (1), and S. cohnii (1). For the characterization and phylogenetic analyses, a total of $23 \mathrm{~S}$. aureus were randomly selected. Most of them were resistant to oxacillin (78\%), clindamycin (78\%), erythromycin $(70 \%)$, ciprofloxacin $(61 \%)$, and gentamicin $(52 \%)$, and all isolates showed sensitivity to vancomycin and linezolid (Table 2). 
Table 2. Presence of virulence factor and antibiotic resistance profile of the 23 S. aureus, and their distribution in sequence type (ST) and clonal complex (CC). Blood samples were collected from patients treated at different public hospitals in São Luis, Northeast Brazil, and submitted to antimicrobial susceptibility testing, as well as to the detection of several virulence and resistance genes.

\begin{tabular}{|c|c|c|c|c|c|c|c|c|c|c|c|c|c|c|c|c|c|c|c|c|}
\hline \multirow[b]{2}{*}{$\mathrm{CC}$} & \multirow[b]{2}{*}{ ST } & \multirow[b]{2}{*}{ Isolates } & \multicolumn{10}{|c|}{ Virulence Factor Profile } & \multicolumn{8}{|c|}{ Antibiotics Resistance Profile } \\
\hline & & & blaZ & clfA & $e b p S$ & $f n b p A$ & hla & $h l b$ & $h l g$ & icaA & mecA & $p v l$ & CIP & CLI & ERI & GEN & OXA & RIF & TEI & TRI \\
\hline CC1 & 97 & 1522 & - & - & + & + & - & + & - & + & + & - & + & + & + & + & + & - & - & - \\
\hline $\mathrm{CC} 1$ & 97 & 1523 & - & - & - & - & - & + & - & + & + & - & - & - & - & - & - & + & - & - \\
\hline $\mathrm{CC} 1$ & 97 & 1521 & - & - & + & - & - & + & - & + & - & - & + & + & + & + & + & - & - & - \\
\hline CC17 & 101 & 1500 & - & - & - & - & + & - & - & - & - & - & - & - & + & - & - & - & - & - \\
\hline CC2 & 30 & 1507 & + & - & + & + & - & + & + & + & + & + & + & + & + & + & + & - & + & - \\
\hline CC7 & 398 & 1520 & - & - & - & - & - & + & - & + & - & - & - & + & - & - & + & - & - & - \\
\hline $\mathrm{CC} 13 *$ & 5431 & 1514 & - & - & - & - & - & + & - & - & - & - & - & + & - & - & + & - & - & - \\
\hline $\mathrm{CC} 1 *$ & 5429 & 1506 & - & - & - & - & + & + & - & - & - & - & + & + & + & + & + & - & - & - \\
\hline $\mathrm{CC} 1 *$ & 5430 & 1512 & - & - & + & + & - & + & - & + & + & - & + & + & + & + & + & - & - & - \\
\hline CC1 & 461 & 1509 & - & - & + & - & - & + & - & - & - & - & + & + & + & + & + & - & - & - \\
\hline $\mathrm{CC} 1 * *$ & 5433 & 1519 & + & - & + & - & - & + & - & + & - & - & + & + & + & + & + & - & - & - \\
\hline CC1 & 2779 & 1502 & + & - & + & - & - & + & - & + & - & - & - & + & + & - & - & - & - & - \\
\hline $\mathrm{CC} 1 *$ & 5432 & 1516 & + & - & + & - & - & - & - & - & + & - & + & + & + & + & + & - & - & - \\
\hline CC1 & 5 & 1524 & - & - & - & - & - & + & - & + & + & - & - & - & + & - & - & - & - & - \\
\hline CC1 & 5 & 1518 & - & + & - & - & - & + & - & - & - & - & - & - & - & - & + & + & - & + \\
\hline CC1 & 5 & 1517 & + & + & + & - & - & + & - & + & - & - & + & + & + & + & + & - & - & - \\
\hline $\mathrm{CC} 1$ & 5 & 1515 & + & - & + & - & - & + & - & - & - & - & + & + & + & - & + & + & - & - \\
\hline CC1 & 5 & 1501 & + & - & + & + & - & + & - & + & - & - & - & + & - & - & - & - & - & - \\
\hline CC1 & 5 & 1503 & - & - & + & + & - & + & - & + & + & - & + & + & + & + & + & - & - & - \\
\hline CC1 & 5 & 1505 & + & - & - & + & - & - & - & + & + & - & + & + & + & + & + & - & - & - \\
\hline $\mathrm{CC} 1$ & 5 & 1510 & - & + & + & - & - & + & - & - & - & - & + & + & - & - & + & - & - & - \\
\hline $\mathrm{CC} 1$ & 5 & 1511 & - & - & - & - & - & + & - & - & - & - & + & + & + & + & + & - & - & - \\
\hline CC1 & 5 & 1508 & + & - & - & - & - & + & - & - & - & - & - & - & - & - & + & + & - & + \\
\hline \multirow{2}{*}{ Total } & $\mathbf{n}$ & 23 & 11 & 13 & 14 & 4 & 2 & 19 & 1 & 3 & 8 & 1 & 14 & 18 & 16 & 12 & 18 & 4 & 1 & 2 \\
\hline & $\%$ & $100 \%$ & $48 \%$ & $57 \%$ & $61 \%$ & $17 \%$ & $8 \%$ & $83 \%$ & $4 \%$ & $13 \%$ & $35 \%$ & $4 \%$ & $61 \%$ & $78 \%$ & $70 \%$ & $52 \%$ & $78 \%$ & $17 \%$ & $4 \%$ & $9 \%$ \\
\hline
\end{tabular}

${ }^{*}$ CC based on 6 alleles; ** CC inferred by dendrogram / CIP: Ciprofloxacin; CLI: Clindamycin; ERI: Erythromycin; GEN: Gentamycin; OXA: Oxacillin; RIF: Rifampicin; TEI: Teicoplanin;

TRI: Trimethoprim-Sulfamethoxazole / (+): resistant and (-): sensitive / CC: clonal complex; sequence type (ST). 


\subsection{S. aureus Strains Isolated from Blood Infections Displayed a Diversity of Virulence and Resistance Genes}

Given the high levels of drug resistance in $S$. aureus, the presence of several genes associated with virulence and resistance pathways was investigated. A total of 8 strains $(35 \%)$ were positive for the mecA gene, while 11 isolates (48\%) harbored blaZ. Only three strains carried both mecA and blaZ genes (strains 1503, 1505, 1522). Regarding the virulence genes, the most prevalent was hlb (83\%), followed by ebpS (61\%), icaA (57\%), frbpA (17\%), clfA (13\%), and pvl (4\%) (Table 2). However, none of these isolates harbored the tsst, sea, seb, sec, sed, sec, see, seh, sej, eta, or etb gene.

The evaluation of gene combinations revealed that most of the S. aureus isolates (52\%) harbored both $h l b$ and ebpS genes, and some isolates harbored them in combination with others: icaA, blaZ, fnbp $A$, and mecA. Particularly, S. aureus 1507 presented a high variety of resistance and virulence genes: $h l b$, $e b p S, i c a A, b l a Z, f n b p A, m e c A, h l b, h l g$, as well as the pol gene (Table 2).

\subsection{MLST Analysis}

MLST analysis identified seven STs among 18 isolates. Most of them belonged to ST5 (38\%), followed by ST97 (12\%), ST398 (4\%), ST101 (4\%), ST30 (4\%), ST461 (4\%), and ST2779 (4\%). Five isolates (strains 1506, 1512, 1514, 1516, and 1519) had unknown yqiL nucleotide sequences, did not belonging to any ST. Therefore, the multiple alignment analysis of these five strains and the consensus sequence based on all sequence types were deposited in the MLST database, and the new STs were classified: $5429,5430,5431,5432$, and 5433 , respectively to the five isolates.

The eBURST analysis identified 18 strains belonging to CC1 (ST5, ST97, ST461, and ST2779), CC2 (ST30), CC7 (ST398), and CC17 (ST101). This analysis was conducted for the five strains (1506, 1512, 1514, and 1516) using six alleles (except for yqiL) to identify the most related STs and the corresponding CCs. Strain 1519 has a sequence type 631 for $\operatorname{arcC}$ and, based on six alleles, has ST5286, and has a new yqiL sequence, thus the CC could not be identified. The classification of this strain on CC1 was inferred by phylogenetic analysis (Figure 1). Regarding the three strains 1512, 1516, and 1506, belonging to CC1, two of them, 1512 and 1516, have six identical alleles with the ST5 group. The other strain 1506 has six identical alleles with the ST15 group. Strain 1514 has six identical alleles with the ST7 group of the CC13 (Table 2, Figure 1A). Additionally, we constructed a phylogeny of all 23 strains (Figure 1B). Phylogenetic analysis showed that strain 1519 is closely related with ST461 (strain 1509) and ST2779 (strain 1502), belonging to the CC1 group. 


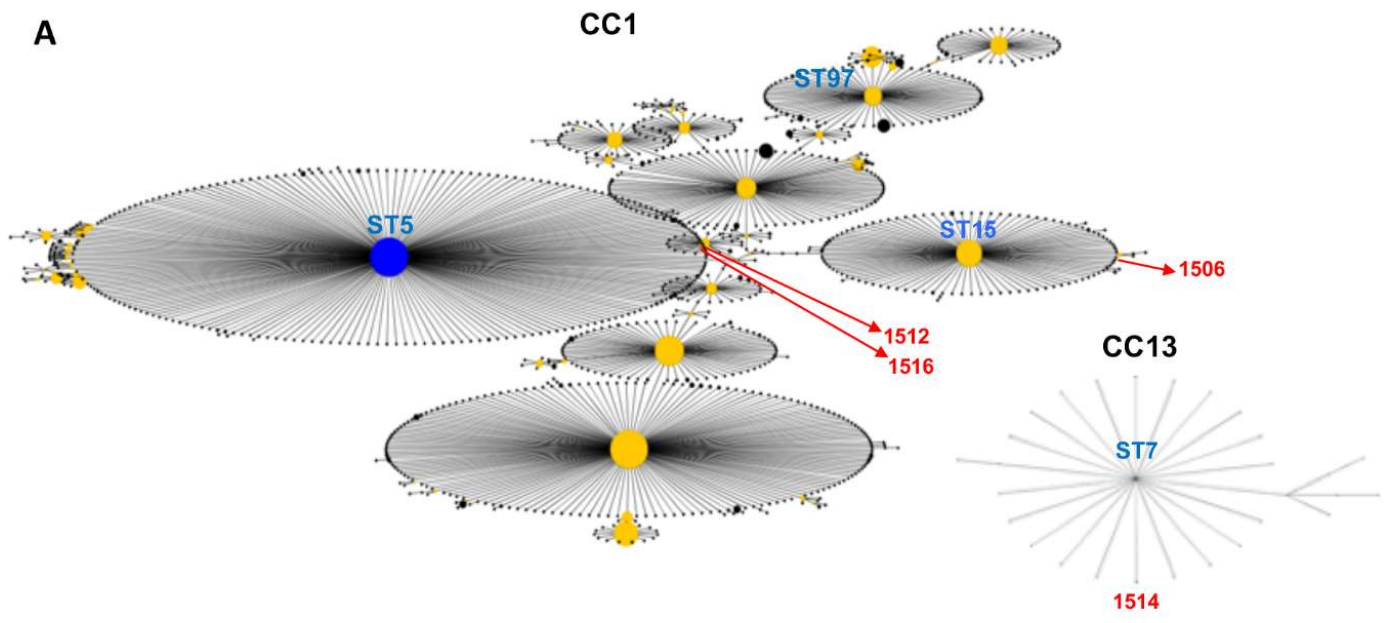

B

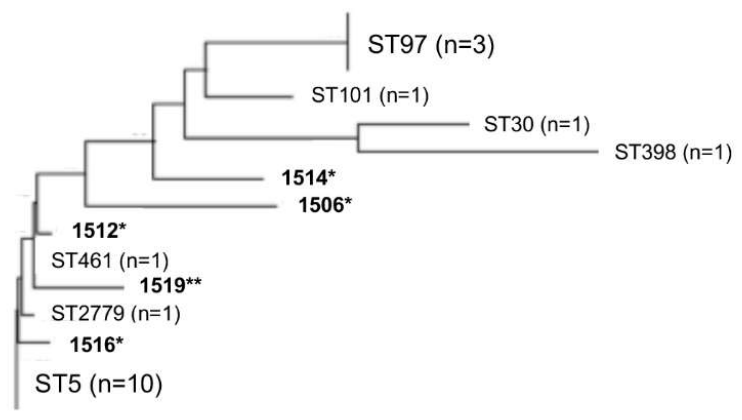

Figure 1. Clonal complex eBURST group analysis and the genetic relationship of the 23 S. aureus isolates. (A) The eBURST group was obtained for the four strains 1506, 1512, 1514, and 1516, based on six identical alleles (except for yqiL, four new sequences). The size of the circles shows the number of isolates for each ST (node), and the central node indicates the most prevalent ST in the CC group. Blue or yellow nodes indicate ST group founder or ST subgroup founder, respectively. The black line indicates one different allele between two ST groups. (B) Phylogeny shows the genetic relationship of strain 1519. * Indicates the strains also analyzed by eBURST and ** indicates the strain from which CC was inferred by phylogenetic analysis. A number between parentheses corresponds to the number of isolates.

\section{Discussion}

The emergence and spread of pathogens, such as S. aureus, is an important public health concern, making a better characterization of the virulence and drug resistance profiles of these strains of vital importance. In this study, we employed different approaches to evaluate the genetic diversity of S. aureus strains isolated from bloodstream infections in patients at several hospitals in São Luís (Northeast Brazil).

Among the S. aureus strains evaluated in this study, about $78 \%$ were MRSA. The isolation of MRSA has been common worldwide. This pathogen is one of the leading causes of nosocomial infections [31], representing $63 \%$ of staphylococcal infections $[8,19]$. In Brazil, several studies have demonstrated a prevalence of hospital-acquired S. aureus infections varying from $17 \%$ to $26 \%$, and, approximately $70 \%$ to $100 \%$ of these infections are caused by multidrug-resistant strains $[8,18,32]$.

In particular, a previous study performed in this same area using strains isolated from different samples of patients reported a prevalence of $29.4 \%$ for MRSA [32]. Therefore, our study indicates that there was a drastic increase in MRSA over the last decade. This phenomenon has also been observed in other studies, and it has been associated with different aspects such as the indiscriminate use of antibiotics in different contexts, socio-economic and environmental factors, migrations and hygienic conditions $[8,18,33,34]$. Increased bacterial resistance towards several antimicrobials makes 
vancomycin the drug of choice for the treatment of S. aureus MDR strains. Strains with resistance to vancomycin or linezolid were not observed in this study; however, VRSA isolates have been reported worldwide, including in Brazil since December 2012 [35]. In this way, the importance of analyzing the sensitivity profile of microorganisms to antimicrobial drugs is emphasized, because it is then possible to understand how they are distributed and how the choice of antibiotics should be made [36].

Regarding the detection of virulence factors, the hlb gene (which encodes hemolysin B) was detected in $83 \%$ of the S. aureus strains. B-hemolysin has both sphingomyelinase and DNA biofilm ligase activities, and it can lysis a range of host cell membranes. This cytotoxin is very prevalent in S. aureus strains, and, although its exact contribution to $S$. aureus virulence remains unsolved, this toxin has been associated with cases of furunculosis, endocarditis chronic osteomyelitis, and respiratory infections in humans, and with mastitis in animals. The toxin also enhances the activity of phenol-soluble modulin, and its activity is enhanced by superantigens [27,37-39].

Other genes, such as ebpS, icaA, fnbpA, clfA, and $p v l$, were also detected in both MRSA and methicillin-sensitive isolates (MSSA). However, the gene encoding PVL was only identified in one MRSA isolate. This strain also showed the higher number of virulence genes. Most isolates carrying the pvl gene are MRSA, and a report showed an increase in pol-positive strains in the period 2005-2009, where the minority of the isolates were methicillin-sensitive [40]. PVL confers increased virulence to S. aureus strains and it is believed that this toxin is a key factor in pneumonia pathogenesis. Furthermore, it induces toxic effects in neutrophils, intensifying the damage related to necrotizing pneumonia in humans $[41,42]$.

Besides that, we investigated the presence of genes related to tissue adhesion and encoding proteins present on the cell surface. The results showed that ebpS (encoding the elastin-binding protein) and fnbp A (encoding fibronectin-binding protein A) genes were present in $61 \%$ and $17 \%$ of the S. aureus, respectively. Both $f n b p A$ and $e b p S$ appear to be widely distributed among S. aureus in hospitalized patients, and the frequency of these genes has varied in accordance with the type of sample and area studied [43-47]. It is worth mentioning that the binding of EbpS (encoded by ebpS) with elastin may promote bacterial colonization to facilitate pathogenesis [48]. In addition, the fnbpA gene is responsible for the expression of host adhesion and invasion proteins, and may be related to biofilm formation. Thus, FnbpA encoded by fnbpA is a very relevant factor for the action of bacterial pathogens in humans [49].

It is also worth highlighting the high prevalence of icaA (57\%) in these strains; this gene was present in almost all MRSA strains. Various studies have also reported the high prevalence of MRSA carrying icaA $[44,47]$. This gene is associated with biofilm formation, a well-known risk factor for chronic infection, which constitutes a suitable environmental for the horizontal transfer of genes [50-53].

The ability to identify S. aureus correctly is important for understanding it and for making public health decisions. S. aureus has a diverse clonal population and studies have shown, through the MLST technique, that a small set of clonal complexes are associated with MRSA epidemics [54-56]. In addition, MLST has been used to characterize and investigate the distribution of S. aureus clones associated with human infections [8,57-62].

Based on the frequency of the virulence and antibiotic resistance genes (ARGs) found in this study, some housekeeping genes were sequenced for phylogenetic evaluation. This analysis allowed the distribution of these S. aureus isolated from bloodstream infections in five clonal complexes and seven STs. In these, the ST5 clone was the most frequent in our study, a result that corroborates those found in a prospective cohort multicenter study of $S$. aureus bacteremia conducted in Latin America in 2011-2014 [8] and Minnesota (USA) in 2015 [61]. ST5 was also the most prevalent in a recent study carried in China [46]. There is evidence to support that the ST5 clone has spread from humans to poultry [63] and is also present in dairy environments in the USA [64], in the Brazilian dairy industry [65], and in chickens [66].

It is known that clonal diversity in S. aureus differs according to the country or region, and that clones differ in antimicrobial resistance patterns and virulence factors [67]. In this study, we also 
showed a high frequency of the ST97 clone among the S. aureus isolates. This clone has been also recovered in the majority of isolated cases related with bovine mastitis [34,68]. In addition, the MRSA ST97 clone has been also described in pigs [69]. It is interesting to mention that these studies showed different species of animals sharing the same ST among them.

In this study, only one S. aureus isolate was classified as a ST398 clone. This ST398 of clonal lineage does not seem to be frequently represented among the S. aureus population [70]; however, it has been involved in sporadic cases of clinical disease with variable severity in humans [68,70-75]. The clonal complex 398 is among the most important livestock-associated S. aureus genotypes, and contact with animals is a well-described risk factor for infection in humans [60]. It has been found in pigs and in the nasal cavity of pig farmers in France [73,76], in swine herds [77], and in bovines [78].

In addition, one S. aureus strain belonging to the ST30 clone and carrying the pol gene was detected in this study. Since the mid-1990s, MRSA ST30 clones with different types and genetic characteristics have been reported in many parts of the world [79]. These S. aureus strains are a major source of high-risk infection globally [80], and ST30 isolates carrying pvl are often associated with necrotizing pneumonia, which causes high morbidity and mortality rates in children $[67,79,81]$.

The CC1 and CC2 groups seem to harbor most of the S. aureus isolates with multidrug resistance profiles. It is interesting to note that all four new STs (CC1 group) have multidrug resistance profiles (CIP, CLI, ERI, GEN, OXA, Table 2), and these STs are closely related. In addition, two strains of these new STs have many virulence genes (more than four). Moreover, the strains of ST5 and ST97 presented different virulence profiles; this result shows horizontal gene acquisition. It is noteworthy that S. aureus strains that are genetically closely related or that belong to the same ST were found in different hospitals, suggesting a spread of bacteria from the same clone in different environments. This is worrying since these bacteria can be disseminated from one hospital to another through the wrong medical and aseptic conduct of the health professional or through patient transfer between hospitals.

\section{Conclusions}

In summary, this study reports that $S$. aureus strains isolated from blood infections present a very high antimicrobial resistance profile, with ST5 and ST97 clones being the most frequent among S. aureus strains. In addition, it was possible to classify five new STs: $5429,5430,5431,5432$, and 5433. This population was mainly composed of MRSA isolates that presented a high and diverse frequency of virulence genes, representing a potential risk to public health. In addition, phylogenetic analysis can be useful for microbial characterization, knowledge, and the control of circulating bacterial clones in hospitals. Thus, the rapid identification of the causative agent of infection, antimicrobial susceptibility testing, and molecular techniques are very important in order to adjust the appropriate therapy and avoid ineffective treatments for microbial infections.

Author Contributions: A.d.S.M., B.L.S.P., and A.G.A. conceived the study and performed the study design. A.d.S.M., B.L.S.P., J.d.M.M., R.M.F., P.C.S.R., S.G.M., W.R.N.N., G.F.F., M.R.Q.B., and A.G.A. performed the microbiological assays. B.L.S.P., M.R.Q.B., and S.Y.B. performed DNA sequencing and Multilocus Sequence Typing. A.d.S.M., L.C.N.S., and A.G.A. wrote the paper. All author discussed the results and approved the final version of this manuscript.

Funding: This research was funded by FAPEMA (Fundação de Amparo à Pesquisa e ao Desenvolvimento Científico e Tecnológico do Maranhão), São Luís, Brazil, grant numbers: 01278/17 and 00559/14.

Acknowledgments: We would like to thank the Universidade Ceuma (UNICEUMA-São Luis-MA, Brazil) and Fundação de Amparo à Pesquisa e ao Desenvolvimento Científico e Tecnológico do Maranhão (FAPEMA-São Luis-MA, Brazil).

Conflicts of Interest: The authors declare no financial or commercial conflict of interest.

\section{References}

1. Ferrer, R.; Martin-Loeches, I.; Phillips, G.; Osborn, T.M.; Townsend, S.; Dellinger, R.P.; Artigas, A.; Schorr, C.; Levy, M.M. Empiric antibiotic treatment reduces mortality in severe sepsis and septic shock from the first hour: 
Results from a guideline-based performance improvement program. Crit. Care Med. 2014, 42, 1749-1755. [CrossRef] [PubMed]

2. Opota, O.; Croxatto, A.; Prod'hom, G.; Greub, G. Blood culture-based diagnosis of bacteraemia: state of the art. Clin. Microbiol. Infect. 2015, 21, 313-322. [CrossRef]

3. Friedrich, A.W. Control of hospital acquired infections and antimicrobial resistance in Europe: The way to go. Wien. Med. Wochenschr. 2019, 169, 25-30. [CrossRef] [PubMed]

4. Shafer, C.; Allison, J.; Hogue, A.; Huntington, M. Infectious Disease: Health Care-Associated Infections. Fp. Essent. 2019, 476, 30-42. [PubMed]

5. Pliakos, E.E.; Andreatos, N.; Ziakas, P.D.; Mylonakis, E. The Cost-effectiveness of Antimicrobial Lock Solutions for the Prevention of Central Line-Associated Bloodstream Infections. Clin. Infect. Dis. 2019, 68, 419-425. [CrossRef] [PubMed]

6. Talan, D.A.; Krishnadasan, A.; Gorwitz, R.J.; Fosheim, G.E.; Limbago, B.; Albrecht, V.; Moran, G.J.; Group, E.M.I.N.S. Comparison of Staphylococcus aureus from skin and soft-tissue infections in US emergency department patients, 2004 and 2008. Clin. Infect. Dis. 2011, 53, 144-149. [CrossRef] [PubMed]

7. Laupland, K.B. Incidence of bloodstream infection: a review of population-based studies. Clin. Microbiol Infect. 2013, 19, 492-500. [CrossRef] [PubMed]

8. Arias, C.A.; Reyes, J.; Carvajal, L.P.; Rincon, S.; Diaz, L.; Panesso, D.; Ibarra, G.; Rios, R.; Munita, J.M.; Salles, M.J.; et al. A Prospective Cohort Multicenter Study of Molecular Epidemiology and Phylogenomics of Staphylococcus aureus Bacteremia in Nine Latin American Countries. Antimicrob. Agents Chemother. 2017, 61. [CrossRef]

9. Wang, B.; Muir, T.W. Regulation of Virulence in Staphylococcus aureus: Molecular Mechanisms and Remaining Puzzles. Cell Chem. Biol. 2016, 23, 214-224. [CrossRef] [PubMed]

10. Buchan, K.D.; Foster, S.J.; Renshaw, S.A. Staphylococcus aureus: Setting its sights on the human innate immune system. Microbiology 2019, 165, 367-385. [CrossRef]

11. Duan, J.; Li, M.; Hao, Z.; Shen, X.; Liu, L.; Jin, Y.; Wang, S.; Guo, Y.; Yang, L.; Wang, L.; et al. Subinhibitory concentrations of resveratrol reduce alpha-hemolysin production in Staphylococcus aureus isolates by downregulating saeRS. Emerg. Microbes. Infect. 2018, 7, 136. [CrossRef] [PubMed]

12. Rebic, V.; Budimir, A.; Aljicevic, M.; Mahmutovic Vranic, S.; Rebic, D. Panton-Valentine leukocidin and staphylococcal cassette chromosome mec characterization of community acquired methicillin-resistant Staphylococcus aureus. Cent. Eur. J. Public Health 2019, 27, 58-63. [CrossRef] [PubMed]

13. Foster, T.J.; Geoghegan, J.A.; Ganesh, V.K.; Hook, M. Adhesion, invasion and evasion: the many functions of the surface proteins of Staphylococcus aureus. Nat. Rev. Microbiol. 2014, 12, 49-62. [CrossRef] [PubMed]

14. Nakakido, M.; Aikawa, C.; Nakagawa, I.; Tsumoto, K. The staphylococcal elastin-binding protein regulates zinc-dependent growth/biofilm formation. J. Biochem. 2014, 156, 155-162. [CrossRef]

15. Ge, B.; Mukherjee, S.; Hsu, C.-H.; Davis, J.A.; Tran, T.T.T.; Yang, Q.; Abbott, J.W.; Ayers, S.L.; Young, S.R.; Crarey, E.T. MRSA and multidrug-resistant Staphylococcus aureus in US retail meats, 2010-2011. Food Microbiol. 2017, 62, 289-297. [CrossRef]

16. Fischbach, M.A.; Walsh, C.T. Antibiotics for emerging pathogens. Science 2009, 325, 1089-1093. [CrossRef]

17. Boucher, H.W.; Talbot, G.H.; Bradley, J.S.; Edwards, J.E.; Gilbert, D.; Rice, L.B.; Scheld, M.; Spellberg, B.; Bartlett, J. Bad bugs, no drugs: no ESKAPE! An update from the Infectious Diseases Society of America. Clin. Infect. Dis. 2009, 48, 1-12. [CrossRef]

18. Seas, C.; Garcia, C.; Salles, M.J.; Labarca, J.; Luna, C.; Alvarez-Moreno, C.; Mejia-Villatoro, C.; Zurita, J.; Guzman-Blanco, M.; Rodriguez-Noriega, E.; et al. Staphylococcus aureus bloodstream infections in Latin America: results of a multinational prospective cohort study. J. Antimicrob. Chemother. 2018, 73, $212-222$. [CrossRef]

19. Guzmán-Blanco, M.; Mejía, C.; Isturiz, R.; Alvarez, C.; Bavestrello, L.; Gotuzzo, E.; Labarca, J.; Luna, C.M.; Rodríguez-Noriega, E.; Salles, M.J. Epidemiology of meticillin-resistant Staphylococcus aureus (MRSA) in Latin America. Int. J. Antimicrob. Agents 2009, 34, 304-308. [CrossRef]

20. Omuse, G.; Zyl, K.N.; Hoek, K.; Abdulgader, S.; Kariuki, S.; Whitelaw, A.; Revathi, G. Molecular characterization of Staphylococcus aureus isolates from various healthcare institutions in Nairobi, Kenya: A cross sectional study. Ann. Clin. Microbiol. Antimicrob. 2016, 15, 51. [CrossRef] 
21. Dubey, D.; Rath, S.; Sahu, M.C.; Pattnaik, L.; Debata, N.K.; Padhy, R.N. Surveillance of infection status of drug resistant Staphylococcus aureus in an Indian teaching hospital. Asian Pac. J. Trop. Dis. 2013, 3, 133-142. [CrossRef]

22. Menezes, G.A.; Harish, B.N.; Sujatha, S.; Vinothini, K.; Parija, S.C. Emergence of vancomycin-intermediate Staphylococcus species in southern India. J. Med. Microbiol. 2008, 57, 911-912. [CrossRef] [PubMed]

23. Delgado, S.; Garcia, P.; Fernandez, L.; Jimenez, E.; Rodriguez-Banos, M.; del Campo, R.; Rodriguez, J.M. Characterization of Staphylococcus aureus strains involved in human and bovine mastitis. Fems Immunol. Med. Microbiol. 2011, 62, 225-235. [CrossRef] [PubMed]

24. Wu, D.; Li, X.; Yang, Y.; Zheng, Y.; Wang, C.; Deng, L.; Liu, L.; Li, C.; Shang, Y.; Zhao, C.; et al. Superantigen gene profiles and presence of exfoliative toxin genes in community-acquired meticillin-resistant Staphylococcus aureus isolated from Chinese children. J. Med. Microbiol. 2011, 60, 35-45. [CrossRef] [PubMed]

25. Karahan, Z.C.; Dolapci, I.; Tekeli, A. Influence of reaction optimization on the results of PCR amplification of Panton-Valentine leukocidin genes among Staphylococcus aureus isolates. Mikrobiyol. Bul. 2009, 43, 519-528. [PubMed]

26. Boers, S.A.; van der Reijden, W.A.; Jansen, R. High-throughput multilocus sequence typing: bringing molecular typing to the next level. PLoS ONE 2012, 7, e39630. [CrossRef] [PubMed]

27. Herrera, A.; Vu, B.G.; Stach, C.S.; Merriman, J.A.; Horswill, A.R.; Salgado-Pabon, W.; Schlievert, P.M. Staphylococcus aureus beta-Toxin Mutants Are Defective in Biofilm Ligase and Sphingomyelinase Activity, and Causation of Infective Endocarditis and Sepsis. Biochemistry 2016, 55, 2510-2517. [CrossRef] [PubMed]

28. Saitou, N.; Nei, M. The neighbor-joining method: a new method for reconstructing phylogenetic trees. Mol. Biol. Evol. 1987, 4, 406-425.

29. Kimura, M. A simple method for estimating evolutionary rates of base substitutions through comparative studies of nucleotide sequences. J. Mol. Evol 1980, 16, 111-120. [CrossRef]

30. Tamura, K.; Stecher, G.; Peterson, D.; Filipski, A.; Kumar, S. MEGA6: Molecular evolutionary genetics analysis version 6.0. Mol. Biol. Evol. 2013, 30, 2725-2729. [CrossRef]

31. Miller, M.B.; Meyer, H.; Rogers, E.; Gilligan, P.H. Comparison of conventional susceptibility testing, penicillin-binding protein 2a latex agglutination testing, and mecA real-time PCR for detection of oxacillin resistance in Staphylococcus aureus and coagulase-negative Staphylococcus. J. Clin. Microbiol. 2005, 43, 3450-3452. [CrossRef] [PubMed]

32. Abreu, A.G.; Novais, S.G.; Marques, T.M.G.; Gonçalves, A.G. Prevalênca de Staphylococcus aureus resistente à meticilina (MRSA) em hospitais públicos e privados de São Luís, MA, Brasil. Rev. Ciências Da Saúde 2010, 12, 67-72.

33. Dulon, M.; Haamann, F.; Peters, C.; Schablon, A.; Nienhaus, A. MRSA prevalence in European healthcare settings: a review. BMC Infect. Dis. 2011, 11, 138. [CrossRef] [PubMed]

34. Li, T.; Lu, H.; Wang, X.; Gao, Q.; Dai, Y.; Shang, J.; Li, M. Molecular Characteristics of Staphylococcus aureus Causing Bovine Mastitis between 2014 and 2015. Front. Cell Infect. Microbiol. 2017, 7, 127. [CrossRef] [PubMed]

35. Da Costa, T.M.; Morgado, P.G.M.; Cavalcante, F.S.; Damasco, A.P.; Nouér, S.A.; dos Santos, K.R.N. Clinical and microbiological characteristics of heteroresistant and vancomycin-intermediate Staphylococcus aureus from bloodstream infections in a Brazilian teaching hospital. PLoS ONE 2016, 11, e0160506. [CrossRef] [PubMed]

36. McGuinness, W.A.; Malachowa, N.; DeLeo, F.R. Vancomycin Resistance in Staphylococcus aureus. Yale J. Biol. Med. 2017, 90, 269-281. [PubMed]

37. Salgado-Pabon, W.; Herrera, A.; Vu, B.G.; Stach, C.S.; Merriman, J.A.; Spaulding, A.R.; Schlievert, P.M. Staphylococcus aureus beta-toxin production is common in strains with the beta-toxin gene inactivated by bacteriophage. J. Infect. Dis. 2014, 210, 784-792. [CrossRef]

38. Dupieux, C.; Camus, C.; Lina, G.; Vandenesch, F.; Laurent, F.; Rasigade, J.P. Does beta-toxin production contribute to the cytotoxicity of hypervirulent Staphylococcus aureus? J. Infect. Dis. 2015, 211, 846-847. [CrossRef]

39. Herrera, A.; Kulhankova, K.; Sonkar, V.K.; Dayal, S.; Klingelhutz, A.J.; Salgado-Pabon, W.; Schlievert, P.M. Staphylococcal beta-Toxin Modulates Human Aortic Endothelial Cell and Platelet Function through Sphingomyelinase and Biofilm Ligase Activities. MBio 2017, 8. [CrossRef] 
40. Kreienbuehl, L.; Charbonney, E.; Eggimann, P. Community-acquired necrotizing pneumonia due to methicillin-sensitive Staphylococcus aureus secreting Panton-Valentine leukocidin: A review of case reports. Ann. Intensive Care 2011, 1, 52. [CrossRef]

41. Löffler, B.; Hussain, M.; Grundmeier, M.; Brück, M.; Holzinger, D.; Varga, G.; Roth, J.; Kahl, B.C.; Proctor, R.A.; Peters, G. Staphylococcus aureus panton-valentine leukocidin is a very potent cytotoxic factor for human neutrophils. PLoS Pathog. 2010, 6, e1000715. [CrossRef] [PubMed]

42. Jiang, B.; Wang, Y.; Feng, Z.; Xu, L.; Tan, L.; Zhao, S.; Gong, Y.; Zhang, C.; Luo, X.; Li, S.; et al. Panton-Valentine Leucocidin (PVL) as a Potential Indicator for Prevalence, Duration, and Severity of Staphylococcus aureus Osteomyelitis. Front. Microbiol. 2017, 8, 2355. [CrossRef] [PubMed]

43. Tristan, A.; Ying, L.; Bes, M.; Etienne, J.; Vandenesch, F.; Lina, G. Use of multiplex PCR to identify Staphylococcus aureus adhesins involved in human hematogenous infections. J. Clin. Microbiol. 2003, 41, 4465-4467. [CrossRef] [PubMed]

44. Bimanand, L.; Taherikalani, M.; Jalilian, F.A.; Sadeghifard, N.; Ghafourian, S.; Mahdavi, Z.; Mohamadi, S.; Sayehmiri, K.; Hematian, A.; Pakzad, I. Association between biofilm production, adhesion genes and drugs resistance in different SCCmec types of methicillin resistant Staphylococcus aureus strains isolated from several major hospitals of Iran. Iran. J. Basic Med. Sci. 2018, 21, 400. [PubMed]

45. Soltani, E.; Farrokhi, E.; Zamanzad, B.; Abadi, M.S.S.; Deris, F.; Soltani, A.; Gholipour, A. Prevalence and distribution of adhesins and the expression of fibronectin-binding protein (FnbA and FnbB) among Staphylococcus aureus isolates from Shahrekord Hospitals. BMC Res. Notes 2019, 12, 49. [CrossRef] [PubMed]

46. Li, X.; Fang, F.; Zhao, J.; Lou, N.; Li, C.; Huang, T.; Li, Y. Molecular characteristics and virulence gene profiles of Staphylococcus aureus causing bloodstream infection. Braz. J. Infect. Dis. 2018, 22, 487-494. [CrossRef] [PubMed]

47. Haddad, O.; Merghni, A.; Elargoubi, A.; Rhim, H.; Kadri, Y.; Mastouri, M. Comparative study of virulence factors among methicillin resistant Staphylococcus aureus clinical isolates. BMC Infect. Dis. 2018, 18, 560. [CrossRef] [PubMed]

48. Downer, R.; Roche, F.; Park, P.W.; Mecham, R.P.; Foster, T.J. The elastin-binding protein of Staphylococcus aureus (EbpS) is expressed at the cell surface as an integral membrane protein and not as a cell wall-associated protein. J. Biol. Chem. 2002, 277, 243-250. [CrossRef]

49. Serray, B.; Oufrid, S.; Hannaoui, I.; Bourjilate, F.; Soraa, N.; Mliji, M.; Sobh, M.; Hammoumi, A.; Timinouni, M.; El Azhari, M. Genes encoding adhesion factors and biofilm formation in methicillin-resistant Staphylococcus aureus in Morocco. J. Infect. Dev. Ctries. 2016, 10, 863-869. [CrossRef]

50. Gowrishankar, S.; Kamaladevi, A.; Balamurugan, K.; Pandian, S.K. In vitro and in vivo biofilm characterization of methicillin-resistant Staphylococcus aureus from patients associated with pharyngitis infection. Biomed Res. Int. 2016, 2016. [CrossRef]

51. Marques, V.F.; Motta, C.C.; Soares, B.D.; Melo, D.A.; Coelho, S.M.; Coelho, I.D.; Barbosa, H.S.; Souza, M.M. Biofilm production and beta-lactamic resistance in Brazilian Staphylococcus aureus isolates from bovine mastitis. Braz. J. Microbiol. 2017, 48, 118-124. [CrossRef] [PubMed]

52. Madsen, J.S.; Burmolle, M.; Hansen, L.H.; Sorensen, S.J. The interconnection between biofilm formation and horizontal gene transfer. Fems Immunol. Med. Microbiol. 2012, 65, 183-195. [CrossRef] [PubMed]

53. Aguila-Arcos, S.; Alvarez-Rodriguez, I.; Garaiyurrebaso, O.; Garbisu, C.; Grohmann, E.; Alkorta, I. Biofilm-Forming Clinical Staphylococcus Isolates Harbor Horizontal Transfer and Antibiotic Resistance Genes. Front. Microbiol. 2017, 8, 2018. [CrossRef] [PubMed]

54. Wang, W.Y.; Chiueh, T.S.; Sun, J.R.; Tsao, S.M.; Lu, J.J. Molecular typing and phenotype characterization of methicillin-resistant Staphylococcus aureus isolates from blood in Taiwan. PLoS ONE 2012, 7, e30394. [CrossRef] [PubMed]

55. Chen, X.; Wang, W.K.; Han, L.Z.; Liu, Y.; Zhang, H.; Tang, J.; Liu, Q.Z.; Huangfu, Y.C.; Ni, Y.X. Epidemiological and genetic diversity of Staphylococcus aureus causing bloodstream infection in Shanghai, 2009-2011. PLoS ONE 2013, 8, e72811. [CrossRef] [PubMed]

56. Abdulgader, S.M.; Shittu, A.O.; Nicol, M.P.; Kaba, M. Molecular epidemiology of Methicillin-resistant Staphylococcus aureus in Africa: A systematic review. Front. Microbiol. 2015, 6, 348. [CrossRef] [PubMed]

57. Chen, R.; Yan, Z.Q.; Feng, D.; Luo, Y.P.; Wang, L.L.; Shen, D.X. Nosocomial bloodstream infection in patients caused by Staphylococcus aureus: Drug susceptibility, outcome, and risk factors for hospital mortality. Chin. Med. J. 2012, 125, 226-229. 
58. Mehndiratta, P.L.; Bhalla, P. Typing of Methicillin resistant Staphylococcus aureus: A technical review. Indian J. Med. Microbiol. 2012, 30, 16-23. [CrossRef] [PubMed]

59. Miko, B.A.; Hafer, C.A.; Lee, C.J.; Sullivan, S.B.; Hackel, M.A.; Johnson, B.M.; Whittier, S.; Della-Latta, P.; Uhlemann, A.C.; Lowy, F.D. Molecular characterization of methicillin-susceptible Staphylococcus aureus clinical isolates in the United States, 2004 to 2010. J. Clin. Microbiol. 2013, 51, 874-879. [CrossRef]

60. Smith, T.C.; Wardyn, S.E. Human Infections with Staphylococcus aureus CC398. Curr. Env. Health Rep. 2015, 2, 41-51. [CrossRef]

61. Park, K.H.; Greenwood-Quaintance, K.E.; Uhl, J.R.; Cunningham, S.A.; Chia, N.; Jeraldo, P.R.; Sampathkumar, P.; Nelson, H.; Patel, R. Molecular epidemiology of Staphylococcus aureus bacteremia in a single large Minnesota medical center in 2015 as assessed using MLST, core genome MLST and spa typing. PLoS ONE 2017, 12, e0179003. [CrossRef] [PubMed]

62. Li, S.; Sun, S.; Yang, C.; Chen, H.; Yin, Y.; Li, H.; Zhao, C.; Wang, H. The Changing Pattern of Population Structure of Staphylococcus aureus from Bacteremia in China from 2013 to 2016: ST239-030-MRSA Replaced by ST59-t437. Front. Microbiol. 2018, 9, 332. [CrossRef] [PubMed]

63. Lowder, B.V.; Guinane, C.M.; Ben Zakour, N.L.; Weinert, L.A.; Conway-Morris, A.; Cartwright, R.A.; Simpson, A.J.; Rambaut, A.; Nubel, U.; Fitzgerald, J.R. Recent human-to-poultry host jump, adaptation, and pandemic spread of Staphylococcus aureus. Proc. Natl. Acad. Sci. USA 2009, 106, 19545-19550. [CrossRef] [PubMed]

64. Matyi, S.A.; Dupre, J.M.; Johnson, W.L.; Hoyt, P.R.; White, D.G.; Brody, T.; Odenwald, W.F.; Gustafson, J.E. Isolation and characterization of Staphylococcus aureus strains from a Paso del Norte dairy. J. Dairy Sci. 2013, 96, 3535-3542. [CrossRef] [PubMed]

65. Silva, N.C.; Guimaraes, F.F.; Manzi, M.P.; Budri, P.E.; Gomez-Sanz, E.; Benito, D.; Langoni, H.; Rall, V.L.; Torres, C. Molecular characterization and clonal diversity of methicillin-susceptible Staphylococcus aureus in milk of cows with mastitis in Brazil. J. Dairy Sci. 2013, 96, 6856-6862. [CrossRef] [PubMed]

66. Nworie, A.; Onyema, A.S.; Okekpa, S.I.; Elom, M.O.; Umoh, N.O.; Usanga, V.U.; Ibiam, G.A.; Ukwah, B.N.; Nwadi, L.C.; Ezeruigbo, C.; et al. A Novel Methicillin-Resistant Staphylococcus aureus t11469 and a Poultry Endemic Strain 0002 (ST5) Are Present in Chicken in Ebonyi State, Nigeria. Biomed. Res. Int. 2017, 2017, 2936461. [CrossRef] [PubMed]

67. Rodriguez-Noriega, E.; Seas, C.; Guzman-Blanco, M.; Mejia, C.; Alvarez, C.; Bavestrello, L.; Zurita, J.; Labarca, J.; Luna, C.M.; Salles, M.J.; et al. Evolution of methicillin-resistant Staphylococcus aureus clones in Latin America. Int. J. Infect. Dis. 2010, 14, e560-e566. [CrossRef] [PubMed]

68. Zhang, L.; Gao, J.; Barkema, H.W.; Ali, T.; Liu, G.; Deng, Y.; Naushad, S.; Kastelic, J.P.; Han, B. Virulence gene profiles: alpha-hemolysin and clonal diversity in Staphylococcus aureus isolates from bovine clinical mastitis in China. BMC Vet. Res. 2018, 14, 63. [CrossRef] [PubMed]

69. Meemken, D.; Blaha, T.; Tegeler, R.; Tenhagen, B.A.; Guerra, B.; Hammerl, J.; Hertwig, S.; Käsbohrer, A.; Appel, B.; Fetsch, A. Livestock Associated Methicillin-Resistant Staphylococcus aureus (LaMRSA) Isolated from Lesions of Pigs at Necropsy in Northwest Germany Between 2004 and 2007. Zoonoses Public Health 2010, 57, e143-e148. [CrossRef] [PubMed]

70. Witte, W.; Strommenger, B.; Stanek, C.; Cuny, C. Methicillin-resistant Staphylococcus aureus ST398 in humans and animals, Central Europe. Emerg. Infect. Dis. 2007, 13, 255. [CrossRef]

71. Lozano, C.; Gómez-Sanz, E.; Benito, D.; Aspiroz, C.; Zarazaga, M.; Torres, C. Staphylococcus aureus nasal carriage, virulence traits, antibiotic resistance mechanisms, and genetic lineages in healthy humans in Spain, with detection of CC398 and CC97 strains. Int. J. Med. Microbiol. 2011, 301, 500-505. [CrossRef] [PubMed]

72. Van Loo, I.; Huijsdens, X.; Tiemersma, E.; de Neeling, A.; van de Sande-Bruinsma, N.; Beaujean, D.; Voss, A.; Kluytmans, J. Emergence of methicillin-resistant Staphylococcus aureus of animal origin in humans. Emerg. Infect. Dis. 2007, 13, 1834-1839. [CrossRef] [PubMed]

73. Van Belkum, A.; Melles, D.C.; Peeters, J.K.; van Leeuwen, W.B.; van Duijkeren, E.; Huijsdens, X.W.; Spalburg, E.; de Neeling, A.J.; Verbrugh, H.A.; Dutch Working Party on, S.; et al. Methicillin-resistant and -susceptible Staphylococcus aureus sequence type 398 in pigs and humans. Emerg. Infect. Dis. 2008, 14, 479-483. [CrossRef] [PubMed]

74. Van Hoecke, H.; Piette, A.; De Leenheer, E.; Lagasse, N.; Struelens, M.; Verschraegen, G.; Dhooge, I. Destructive otomastoiditis by MRSA from porcine origin. Laryngoscope 2009, 119, 137-140. [CrossRef] [PubMed] 
75. André Neto, E.D.; Pereira, R.F.A.; Snyder, R.E.; Machado, T.S.; André, L.S.P.; Cardoso, C.A.A.; Aguiar-Alves, F. Emergence of methicillin-resistant Staphylococcus aureus from clonal complex 398 with no livestock association in Brazil. Memórias Do Inst. Oswaldo Cruz. 2017, 112, 647-649. [CrossRef] [PubMed]

76. Armand-Lefevre, L.; Ruimy, R.; Andremont, A. Clonal comparison of Staphylococcus aureus isolates from healthy pig farmers, human controls, and pigs. Emerg. Infect. Dis. 2005, 11, 711-714. [CrossRef]

77. Song, Z.; Gu, F.F.; Guo, X.K.; Ni, Y.X.; He, P.; Han, L.Z. Antimicrobial Resistance and Molecular Characterization of Staphylococcus aureus Causing Childhood Pneumonia in Shanghai. Front. Microbiol. 2017, 8, 455. [CrossRef]

78. Khemiri, M.; Abbassi, M.S.; Couto, N.; Mansouri, R.; Hammami, S.; Pomba, C. Genetic characterisation of Staphylococcus aureus isolated from milk and nasal samples of healthy cows in Tunisia: First report of ST97-t267-agrI-SCCmecV MRSA of bovine origin in Tunisia. J. Glob. Antimicrob. Resist. 2018, 14, 161-165. [CrossRef]

79. David, M.Z.; Daum, R.S. Community-associated methicillin-resistant Staphylococcus aureus: epidemiology and clinical consequences of an emerging epidemic. Clin. Microbiol. Rev. 2010, 23, 616-687. [CrossRef]

80. Isobe, H.; Takano, T.; Nishiyama, A.; Hung, W.-C.; Kuniyuki, S.; Shibuya, Y.; Reva, I.; Yabe, S.; Iwao, Y.; Higuchi, W. Evolution and virulence of Panton-Valentine leukocidin-positive ST30 methicillin-resistant Staphylococcus aureus in the past 30 years in Japan. Biomed. Res. 2012, 33, 97-109. [CrossRef]

81. Gillet, Y.; Issartel, B.; Vanhems, P.; Fournet, J.-C.; Lina, G.; Bes, M.; Vandenesch, F.; Piémont, Y.; Brousse, N.; Floret, D. Association between Staphylococcus aureus strains carrying gene for Panton-Valentine leukocidin and highly lethal necrotising pneumonia in young immunocompetent patients. Lancet 2002, 359, 753-759. [CrossRef]

(C) 2019 by the authors. Licensee MDPI, Basel, Switzerland. This article is an open access article distributed under the terms and conditions of the Creative Commons Attribution (CC BY) license (http://creativecommons.org/licenses/by/4.0/). 